\title{
MADSAM neuropathy
}

An unusual cause of pseudoathetosis

回

Figure 1 Ulnar and median motor nerve conduction
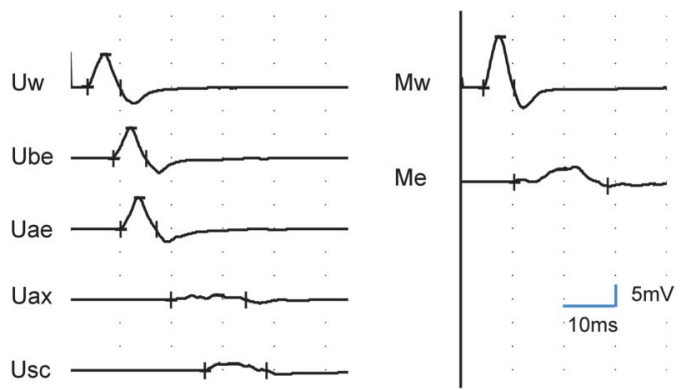

Median and ulnar motor conduction block to supramaximal elbow and axilla stimulation, respectively. ae = above elbow; ax = axilla; be = below elbow; e = elbow; $\mathrm{M}=$ median; $\mathrm{Sc}=$ supraclavicular; $\mathrm{U}=$ ulnar; $\mathrm{w}=$ wrist.
Figure 2 Coronal T2-weighted MRI of the roots/brachial plexus

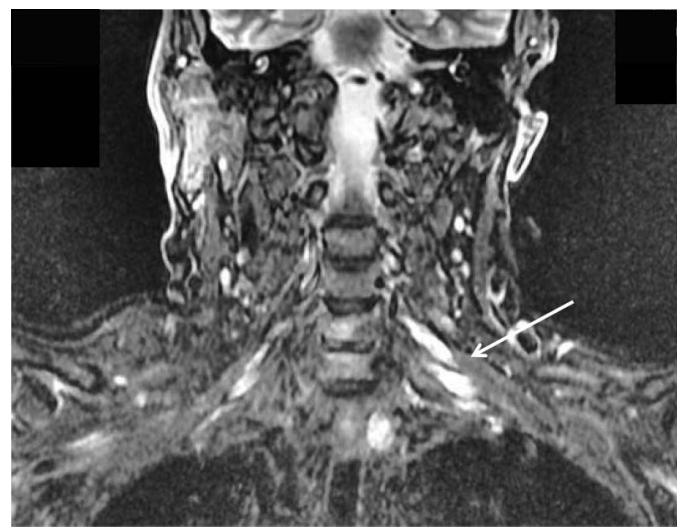

The arrow shows the enlarged left-sided nerve roots and trunks of the brachial plexus. Similar hypertrophy is seen on the right to a lesser extent.

\section{Supplemental data at Neurology.org}

A 68-year-old man complained of several years of an uncoordinated, weak left arm. Clinical examination revealed pseudoathetosis and mild global weakness of the left arm, stocking pattern vibration and pinprick insensitivity, and only mild proprioceptive impairment of the left hand (video on the Neurology ${ }^{\circledR}$ Web site at Neurology.org). Nerve conduction study showed generalized absent or severely attenuated sensory potentials and multiple upper limb motor conduction blocks (figure 1). MRI demonstrated asymmetrically enlarged left nerve roots and trunks of the brachial plexus (figure 2). Chronic inflammatory demyelinating polyradiculoneuropathy can cause tremor, ${ }^{1}$ but multifocal acquired demyelinating sensory and motor neuropathy, ${ }^{2}$ an asymmetric form, has not been reported to cause pseudoathetosis.

\section{Karl Ng, MBBS, FRCP, FRACP, PhD}

From the Royal North Shore Hospital and the University of Sydney, Australia.

Study funding: K. Ng is supported by the National Health and Medical Research Council of Australia (ID 512316).

Disclosure: The author reports no disclosures relevant to the manuscript. Go to Neurology.org for full disclosures.

Correspondence to Dr. Ng: karl.ng@sydney.edu.au

1. Saifee TA, Schwingenschuh P, Reilly MM, et al. Tremor in inflammatory neuropathies. J Neurol Neurosurg Psychiatry 2013;84: $1282-1287$.

2. Saperstein DS, Amato AA, Wolfe GI, et al. Multifocal acquired demyelinating sensory and motor neuropathy: the Lewis-Sumner syndrome. Muscle Nerve 1999;22:560-566. 


\title{
Neurology
}

\author{
MADSAM neuropathy: An unusual cause of pseudoathetosis \\ Karl Ng \\ Neurology 2014;83;291 \\ DOI 10.1212/WNL.0000000000000595
}

This information is current as of July 14, 2014

\section{Updated Information \& Services \\ Supplementary Material \\ References \\ Subspecialty Collections}

Permissions \& Licensing

Reprints including high resolution figures, can be found at: http://n.neurology.org/content/83/3/291.full

Supplementary material can be found at: http://n.neurology.org/content/supp1/2014/07/13/83.3.291.DC1

This article cites 2 articles, 1 of which you can access for free at: http://n.neurology.org/content/83/3/291.full\#ref-list-1

This article, along with others on similar topics, appears in the following collection(s):

All clinical neurophysiology

http://n.neurology.org/cgi/collection/all_clinical_neurophysiology

All Movement Disorders

http://n.neurology.org/cgi/collection/all_movement_disorders

Chronic inflammatory demyelinating polyneuropathy

http://n.neurology.org/cgi/collection/chronic_inflammatory_demyelinat ing_polyneuropathy

Information about reproducing this article in parts (figures,tables) or in its entirety can be found online at:

http://www.neurology.org/about/about_the_journal\#permissions

Information about ordering reprints can be found online:

http://n.neurology.org/subscribers/advertise

Neurology ${ }^{\circledR}$ is the official journal of the American Academy of Neurology. Published continuously since 1951 , it is now a weekly with 48 issues per year. Copyright @ 2014 American Academy of Neurology. All rights reserved. Print ISSN: 0028-3878. Online ISSN: 1526-632X.

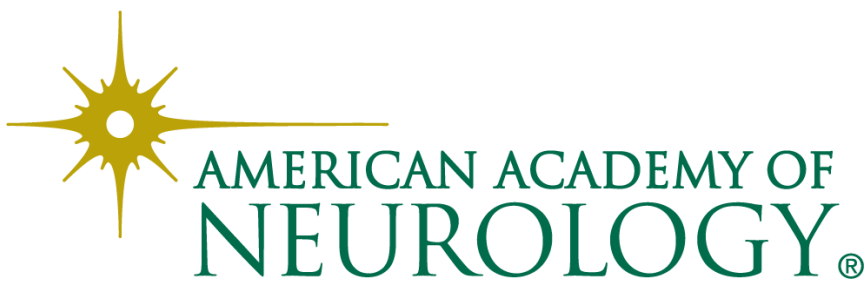

